\title{
Self-efficacy scale for the establishment of good relationships with families in neonatal and pediatric hospital settings*
}

\author{
Escala de autoeficacia para el establecimiento de buenas relaciones \\ con las familias en ambientes neonatales y pediátricos \\ Escala de autoeficácia para o estabelecimento de bons relacionamentos \\ com famílias no contexto neonatal e pediátrico hospitalar
}

Andréia Cascaes Cruz ${ }^{1}$, Margareth Angelo², Bernardo Pereira dos Santos ${ }^{3}$

How to cite this article:

Cruz AC, Angelo M, Santos BP. Self-efficacy scale for the establishment of good relationships with families in neonatal and pediatric hospital settings. Rev Esc Enferm USP. 2017;51:e03222. DOI: http://dx.doi.org/10.1590/S1980-220X2016033803222

* Extracted of the thesis "Relacionamento com famílias na prática clínica de enfermagem no contexto neonatal e pediátrico: impacto de uma intervenção educativa e proposição de uma escala de autoeficácia”, Escola de Enfermagem, Universidade de São Paulo, 2015.

${ }^{1}$ Universidade Federal de São Paulo, Escola Paulista de Enfermagem, São Paulo, SP, Brazil.

${ }^{2}$ Universidade de São Paulo, Escola de Enfermagem, Departamento de Enfermagem Materno-Infantil e Psiquiátrica, São Paulo, SP, Brazil.

${ }^{3}$ Universidade de São Paulo, Escola de Enfermagem, São Paulo, Brazil.

\begin{abstract}
Objective: The purpose of this study was to develop and test the psychometric properties of the Self-efficacy Scale for the Establishment of Good Relationships with Families in Neonatal and Pediatric Hospital Settings. Method: Methodological study grounded on self-efficacy theory was conducted in three phases: conceptual and operational definition (review of the literature and interviews with the target population), content validity (opinion of five experts e three clinical nurses), and exploratory factor analysis and internal consistency reliability (cross-sectional survey with a valid sample of 194 nurses). Results: A ten-point Likert scale with 40 -item was designed and one item was excluded after review by experts. Three factors emerged from the exploratory factor analysis. The Cronbach's alpha for all items was 0.983 with item-total correlations in the range 0.657 to 0.847 . Cronbach's alpha value if item deleted were less than or equal to 0.983. Conclusion: The final version of the scale demonstrated psychometric adequacy. It is a useful tool to be administered in the clinical, educational and research nursing fields to measure nurses' self-efficacy beliefs concerning the establishment of good relationships with families.
\end{abstract}

\section{DESCRIPTORS}

Self Efficacy; Professional-Family Relations; Family Nursing; Neonatal Nursing; Pediatric Nursing; Validation Studies. 


\section{INTRODUCTION}

The core of nursing is caring, the main component of which is the relationship established between the nurse and the care receiver ${ }^{(1)}$. In the pediatric context, despite the physical proximity between families and nurses, professionals impose limits on the interpersonal relationships they establish and the care approach is characterized by detachment and provision of information, marginalizing the relational aspect of care $^{(2-3)}$.

Nurses need to acquire knowledge and develop skills and competencies to relate properly with families. However, this is not enough; it is necessary to integrate the concept of self-efficacy in this process, that is, the perception that nurses have about their own their ability to establish good relationships with families in their care settings ${ }^{(4)}$.

The self-efficacy theory was developed by Albert Bandura, a Canadian psychologist who turned his attention to the role of cognitive processes in the acquisition and maintenance of behaviors. According to social cognitive theory, self-efficacy has a powerful influence on human behavior and can be defined as beliefs that an individual has in their ability to perform a certain task successfully ${ }^{(5)}$. People with a strong sense of efficacy welcome difficult and challenging tasks instead of conceiving them as a threat that must be avoided; they increase and sustain their efforts in the face of failure, and recover their sense of efficacy rapidly after failures or setbacks ${ }^{(6)}$.

Relating to families is a challenge for nurses. Relationships between nurses and the families of hospitalized children are characterized by a lack of clarity regarding both roles; as a result, the difficulties of negotiation permeate the relationships established. Interpersonal relations between nurses and parents are inadequate, inappropriate and ineffective $e^{(2,7-10)}$.

At present, no tool is available for the assessment of nurses' self-efficacy for establishing a good relationship with the family. The closest instrument for the evaluation of these concepts is the Family Nursing Practice Scale, developed by Simpson and Tarrant in 2006, which is developed to measure perceived changes in family nursing practice including nurses attitudes toward working with families, critical appraisal of their family nursing practice and reciprocity in the nurse-family relationship ${ }^{(11)}$.

Considering the importance of the relational aspect of care and the challenges of relating to families, the selfefficacy level perceived by nurses is an important predictor of their behavior in establishing effective relationships with families. In the absence of an instrument that could measure the self-efficacy of nurses to establish good relationships with families, the Self-Efficacy Scale for the Establishment of Good Relationships with Families in Neonatal and Pediatric Hospital Settings was proposed, developed and validated in this study.

The purpose of this study was to develop and test the psychometric properties of the Self-efficacy Scale for the Establishment of Good Relationships with Families in Neonatal and Pediatric Hospital Settings.

\section{METHOD}

Methodological study grounded on self-efficacy theory, whose instrument was developed in line with the methodology of psychometrics, etymologically represented as the theory and technique of measuring mental processes ${ }^{(12-13)}$ and following Bandura's specifications for the construction of instruments for measuring perceived efficacy ${ }^{(14)}$. The study was conducted in three phases: 1 ) conceptual and operational definition; 2) content validity; 3) internal consistency reliability and exploratory factor analysis of the new instrument. These three phases were carried out during the period September 2014 to March 2015.

\section{Phase 1: Conceptual And operational definition}

The conceptual definition deals with the precise insertion of a concept in the theory to which it belongs (self-efficacy theory); it must be precise and clear, as it will contribute to the development of the measuring instrument items and support the construction of the dimensions or factors. The operational definition refers to the preparation of the scale items ${ }^{(12,14)}$, which should be based on open interview analysis conducted with the target population ${ }^{(14)}$. So, the conceptual and operational definition were generated from a review of the literature and an empirical phase (interviews with the target population).

First a literature review on the concept 'Good Relationships between Nurses and Families in Neonatal/ Pediatric Hospital Settings' was carried out. Articles were selected in Portuguese, Spanish and English, published between 2010 and 2015 and indexed in the following databases: MEDLINE (Literatura Internacional em Ciências da Saúde); Cochrane Collaboration PMC (PubMed Central), EMBASE (The Excerpta Medica Database) and CINAHL (Cumulative Index of Nursing and Allied Health Literature). The search strategies employed were adequate for each one of the databases, in general, the following words were used in combination with the Boolean operators as follows: Nurs* AND Famil* OR Parents AND Relationship OR Interaction* OR Relation* AND Neonatal OR Pediatric NOT Primary Health Care. Data collection was performed in four stages: 1) selection by title; 2 ) selection by summary; 3 ) selection by reading the full article and 4) critical evaluation of the quality of the articles. In the end of these stages, 42 studies were included in the literature review for the data analysis.

The second step was to perform interviews with the purpose to understand what mean to have a good relationship with families and to identify elements that hinder or inhibit the relationship of nurses with families in pediatric/neonatal hospital settings in the perception of nurses, since self-efficacy scale items must represent the challenges and impediments to the smooth running of that particular $\operatorname{task}^{(14)}$. The location selected to recruit participants in this phase of the study was a university hospital of high complexity. The principal researcher personally visited pediatric/ neonatal units to invite nurses who directly active in patient care in the pediatric and/or neonatal unit to participate in the study and gave potential participants the information 
about the study, checked their interest and willingness to provide an interview and obtained the written consent of participants. The interviews were conducted in a private room within the hospital units.

Of the nine invited nurses, all agreed to be interviewed. One of them was male and eight were female, they were aged between 24 and 49 years and had worked as a nurse for a period ranging between 10 months and 25 years. The interviews lasted an average of 20 minutes and were guided by a script with pre-prepared questions, such as: Tell me about your day-to-day relationship with families, For you, what does it mean a good relationship with families?, For you, in what situations is it most difficult to relate to families? The interviews were recorded and transcribed. To analyze the data we used inductive content analysis from where emerged codes, categories, and emergent themes, without impose preconceived theoretical perspectives on the data ${ }^{(15,16)}$.

Also in this phase, the gradation for the answers and the corresponding nomenclature median values and the end of the scale were defined ${ }^{(14)}$. The instrument uses a Likert ten-point scale. In the first version, gradation of responses ranged from 0 to 100 , where 0 (zero) represented much uncertainty, 50 (fifty) represented moderate certainty and 100 (one hundred) absolute certainty. After content validation with the committee of experts, the values remained the same, but the nomenclature of scale gradation was modified, as discussed later.

\section{Phase 2: CONTENT VAlidity}

The content validation was performed with two groups of participants: one group comprised five experts (three nurses expert in the family nursing and pediatrics/neonatology area, one nurse expert in the self-efficacy area and one nurse expert in building measuring instruments). The other group comprised three clinical nurses from the pediatric and neonatal area.

The experts were invited by email and agreed, with written consent, to evaluate the first version of the scale in terms of: the semantic appropriateness of the statement, the instructions for completing the instrument, the nomenclature used in grading responses, relevance and understanding of each item. The first version of the instrument was sent by email to experts, along with instructions on how to carry out the evaluation, questions relating to the concept of self-efficacy and explanations of the concept of a good relationship between nurses and families in pediatric/neonatal hospital settings.

There was an $80 \%$ or more correlation between the statement and the items on the instrument and the experts' responses ${ }^{(17)}$. After the necessary modifications to the instrument, according to the evaluation of the group of experts, a new version of the instrument was subjected to an additional semantic analysis with three clinical nurses (this followed the recommendation to apply the instrument to a small group of subjects in the target population (three or four) ${ }^{(17)}$.

The clinical nurses of the same location of the first phase of the study were personally invited by principal researcher to participate in this phase of the study. After agreed with written consent, nurses answered the new version of the instrument and they were asked the following questions: What you did understand was being asked by the instrument; Did you have any difficulty understanding any items on the instrument?; Did you find it difficult to respond to the items using this type of grading? The nurses sent their answers to the principal researcher by e-mail for further analysis.

\section{Phase 3: internal consistency reliability and EXPLORATORY FACTOR ANALYSIS}

A cross-sectional online survey was performed with a convenience sample. To calculate the required sample size it was decided that at least five responders for each item of the instrument ( 5 subjects $\times 39$ items $=195$ subjects $)$ were needed ${ }^{(18)}$. The population in this study was registered nurses who were working in assistance roles in a neonatal and/or pediatric hospital setting. A national neonatal and pediatric nursing association provided an accessible population and all members of this association that had agreed to be contacted for research purposes were invited to participate in the online survey.

An email was sent to 250 potential participants containing: information regarding ethical aspects of the study, the study objectives, collection, analysis, dissemination of data, further consent form and online survey. To ensure the eligibility criteria and characterize the sample, at the end of the survey participants provided information on their gender, age, time in their profession, place of work, unity in the workplace and other variables. A total of 223 nurses responded to the survey, which resulted in a valid sample of 194 nurses after the deletion of 29 respondents who did not actually work in clinical practice. The survey software did not register partially completed survey responses, so the response rate only reflects those who completed the survey.

Data were organized in an Excel 2010 program database and were exported into Statistical Package for the Social Sciences (SPSS) version 22. The internal consistency of the instrument was assessed using three measures: Cronbach's alpha for the total scale, item-total correlation and Cronbach's alpha if the item was deleted. The analysis was performed to full scale, and for each factor. Sampling adequacy was measured using Kaiser-Meyer-Olkin (KMO) and using Barlett's Test of Sphericity for subsequent verification of the dimensionality of the concept through exploratory factor analysis. The KMO compares the magnitude of the relationship between correlation coefficients and partial correlation coefficients. Factor analysis is appropriate when the contents of the KMO are high; the measurement varies between 0 and 1 , and the index must be above 0.5 to perform the factor analysis. The closer KMO is to 1 , the better the result. Bartlett's test of sphericity tests the null hypothesis that the variables in the sample correlation matrix are uncorrelated; the significance level should be low enough (less than or equal to 0.05) for its statistics to be relevant, which means that there is a strong relationship between the variables, rejecting the null hypothesis.

Parallel analysis was performed in order to check how many factors were suggested for the effectuation of the 
factorial analysis of the instrument ${ }^{(19)}$. A common factor analysis by the extraction method of Principal Axis Factoring was then conducted in order to calculate the value of the factor loadings for each item. Only those items with factor loadings equal to or greater than 0.30 were considered. While the extraction technique is designed to maximize independent sources of variance in the correlation matrix, the rotation consists of delineating factors, i.e., to ensure that each item corresponds to a single factor of the concept. The axis of rotation may be orthogonal or oblique; in this study oblique rotation was used, in order to facilitate and improve the interpretation of the factor analysis. After the extraction of factors, an oblique rotation was performed using direct Oblimin solution with Kaiser Normalization, allocating each item to the respective factor, according to the highest value of the factor loadings presented by item for the corresponding factor.

\section{ETHICAL CONSIDERATIONS}

The study was registered and approved by the Research Ethics National Information System (CAAE no 29472414.2.0000.5392 and no 29472414.2.3001.0076) and was approved by the Research Ethics Committees of the School of Nursing of Universidade de São Paulo and the Institution where the study was conducted. All participants gave informed consent following an opportunity to discuss their participation with the researcher. Written consent was obtained from all participants and they were aware that they had the right to stop participating in this study any time without any prejudice to them.

\section{RESULTS}

\section{Phase 1: CONCEPTUAL AND OPERATIONAL DEFINITION}

The concept 'Good Relationships between Nurses and Families in Neonatal/ Pediatric Hospital Settings' is a phenomenon:

Multidimensional, derived from three spheres: cognitive (thoughts and beliefs), affective (feelings), sociocultural (values).

Results from interactions and interpretations that the nurse establishes between her/himself and other individuals, situations, environments and social objects;

Achieved through behaviors or social actions;

Comprised of three interconnected components: connecting with the family, maintaining effective communications with the family and living in harmony with oneself and the family.

Guided by core elements: inclusivity (embracing the family), reliability, availability, appropriate verbal language, active listening, role clarity, empathy, respect.

Forty items were generated for the first version of the Self-efficacy Scale for the Establishment of Good Relationships with Families in Neonatal and Pediatric Hospital Settings.

\section{PhASE 2: CONTENT VALIDITY}

The content validation, carried out with the five experts, resulted in: 1) Changes in the statement and scale instructions: the main change made was the use of the term "confidence" instead of "certainty"; 2) Change in the nomenclature assigned to the values on grading of the responses, "no confidence", "moderate confidence" and "absolute confidence" instead of "much uncertainty", "moderate certainty" and "absolute certainty"; 3) Deleting one item; 4) Semantic and grammatical changes in ten items.

The second version generated after expert evaluations had 39 items. The semantic analysis with the target population did not result in changes in the instrument, since there were no reported problems in the interpretation of the statement, items or nomenclature and score of responses. Thus, the instrument with 39 items was applied to the sample for verification of the psychometric properties.

\section{Phase 3: internal consistency Reliability and EXPLORATORY FACTOR ANALYSIS}

The cross-sectional survey ( $\mathrm{n}=194)$ comprised predominantly female nurses (95.9\%), aged between 31 and 35 years (31.4\%), with 1 to 5 years (33\%) of professional experience. Additional information about the demographic characteristics is shown in Table 1.

Table 1 - Frequency distribution nurse demographic characteristics - São Paulo, SP, Brazil, 2015.

\begin{tabular}{|c|c|c|c|}
\hline \multicolumn{2}{|c|}{ Demographics } & \multirow{2}{*}{$\begin{array}{c}\mathrm{N} \\
12\end{array}$} & \multirow{2}{*}{$\begin{array}{c}\% \% \\
6.2\end{array}$} \\
\hline \multirow{7}{*}{ Age } & 20 to 25 years old & & \\
\hline & 26 to 30 years old & 48 & 24.7 \\
\hline & 31 to 35 years old & 61 & 31.4 \\
\hline & 36 to 40 years old & 31 & 16 \\
\hline & 41 to 45 years old & 14 & 7.2 \\
\hline & 45 to 50 years old & 14 & 7.2 \\
\hline & up to 50 years old & 14 & 7.2 \\
\hline \multirow{4}{*}{$\begin{array}{l}\text { Nursing } \\
\text { qualification }\end{array}$} & Graduate & 16 & 8.2 \\
\hline & Specialist & 118 & 60.8 \\
\hline & Masters degree & 36 & 18.6 \\
\hline & $\mathrm{PhD}$ & 24 & 12.4 \\
\hline \multirow{6}{*}{$\begin{array}{l}\text { Nursing } \\
\text { experience }\end{array}$} & under 1 year & 6 & 3.1 \\
\hline & 1 to 5 years & 64 & 33 \\
\hline & 6 to 10 years & 51 & 26.3 \\
\hline & 11 to 15 years & 34 & 17.5 \\
\hline & 16 to 20 years & 16 & 8.2 \\
\hline & up to 20 years & 23 & 11.9 \\
\hline \multirow{8}{*}{ Unit } & $\begin{array}{l}\text { Neonatal and Pediatric Intensive } \\
\text { Care Unit }\end{array}$ & 15 & 7.7 \\
\hline & Neonatal Intensive Care Unit & 66 & 34 \\
\hline & Pediatric Intensive Care Unit & 43 & 22.2 \\
\hline & Neonatal Unit & 24 & 12.4 \\
\hline & Inpatient Pediatric Unit & 55 & 16.2 \\
\hline & Pediatric Emergency Unit & 24 & 12.4 \\
\hline & Pediatric Oncology Unit & 4 & 2.1 \\
\hline & Pediatric Surgery Unit & 2 & 1 \\
\hline
\end{tabular}


The analysis of internal consistency for the 39 items showed a Cronbach alpha coefficient of 0.983 . The result of the analysis of internal consistency for each of the 39 items of the scale, using the item-total correlation and Cronbach's alpha value if item deleted (Table 2) showed an item-total correlation ranging between 0.657 and 0.847 . All coefficients of the items deleted were less than or equal to 0.983 , indicating the contribution of all items to the internal consistency of the scale.

Table 2 - Internal Consistency Reliability for the 39 items on the Self-efficacy Scale for the Establishment of Good Relationships with Families in Neonatal and Pediatric Hospital Settings - São Paulo, SP, Brazil, 2015.

\begin{tabular}{|c|c|c|}
\hline Item & $\begin{array}{l}\text { Item-total } \\
\text { correlation }\end{array}$ & $\begin{array}{c}\text { Alpha if item } \\
\text { deleted }\end{array}$ \\
\hline 1. Você teve pouco contato com a família. & 0.716 & 0.982 \\
\hline 2. Você não consegue identificar e/ou atender as necessidades da família. & 0.697 & 0.982 \\
\hline 3. A família não está aberta para conversar. & 0.709 & 0.982 \\
\hline 4. A família está alterada emocionalmente (nervosa, agressiva, estressada ou triste). & 0.796 & 0.982 \\
\hline 5. Você conhece pouco a família. & 0.786 & 0.982 \\
\hline 6. A família não compreende o que você está dizendo. & 0.799 & 0.982 \\
\hline 7. A família não sabe quem você é. & 0.763 & 0.982 \\
\hline 8. A família não sabe qual é o seu papel dentro da unidade. & 0.743 & 0.982 \\
\hline 9. A família não se aproxima de você. & 0.721 & 0.982 \\
\hline 10. O seu lado pessoal sobrepõe-se ao profissional. & 0.716 & 0.982 \\
\hline 11. Aquilo que a família pensa ou faz é muito diferente daquilo que você pensaria ou faria. & 0.759 & 0.982 \\
\hline 12. Você não consegue compreender a visão e o modo de viver e agir da família. & 0.828 & 0.982 \\
\hline 13. Você sente que tem uma relação mais pessoal do que profissional com a família. & 0.657 & 0.983 \\
\hline 14. Você acredita que não está preparada (o) para lidar com a família em determinada situação. & 0.795 & 0.982 \\
\hline 15. A família ultrapassa os limites da sua paciência. & 0.750 & 0.982 \\
\hline 16. Ocorre o óbito da criança. & 0.706 & 0.982 \\
\hline 17. A família está numa situação de grande sofrimento. & 0.723 & 0.982 \\
\hline 18. Você está sobrecarregada (o) no trabalho. & 0.726 & 0.982 \\
\hline 19. Você já teve conflitos com a família. & 0.817 & 0.982 \\
\hline 20. O ambiente não oferece condições mínimas de conforto para a família. & 0.783 & 0.982 \\
\hline 21. Falta tempo para você conversar com a família. & 0.755 & 0.982 \\
\hline 22. Você está estressada (o), cansada (o), irritada (o), preocupada (o) ou triste. & 0.787 & 0.982 \\
\hline 23. Há suspeita de maus tratos à criança. & 0.731 & 0.982 \\
\hline 24. Você tem uma impressão negativa da família. & 0.820 & 0.982 \\
\hline 25. Há problemas intrafamiliares. & 0.817 & 0.982 \\
\hline 26. O primeiro contato da equipe de saúde com a família foi inadequado. & 0.832 & 0.982 \\
\hline 27. A criança está em estado grave. & 0.800 & 0.982 \\
\hline 28. A família não aceita a condição em que a criança se encontra. & 0.816 & 0.982 \\
\hline 29. A família não entende o que está acontecendo com a criança. & 0.829 & 0.982 \\
\hline 30. A família é pouco comunicativa. & 0.847 & 0.982 \\
\hline 31. Você não tem respostas para determinadas perguntas da família. & 0.833 & 0.982 \\
\hline 32. A família faz cobranças sobre o seu trabalho. & 0.773 & 0.982 \\
\hline 33. Você sente que a família está responsabilizando você pelo que está acontecendo. & 0.735 & 0.982 \\
\hline 34. A instituição na qual você trabalha não valoriza a presença e o cuidado às famílias. & 0.755 & 0.982 \\
\hline 35. A família teve experiências prévias negativas com outros profissionais ou com outros serviços de saúde. & 0.809 & 0.982 \\
\hline 36. Outros membros da sua equipe não valorizam o relacionamento com as famílias. & 0.783 & 0.982 \\
\hline 37. A família solicita demais. & 0.753 & 0.982 \\
\hline 38. Você sente que a família não confia em você. & 0.716 & 0.982 \\
\hline 39. Você precisa realizar procedimentos invasivos na presença da família. & 0.696 & 0.982 \\
\hline
\end{tabular}


The KMO index presented was high, equal to 0.959 , indicating that the factor analysis could be performed. The Bartlett's test of sphericity was statistically significant, suggesting the suitability of the data for the factor analysis model, indicating that the items were correlated. The parallel analysis suggested that the instrument was constituted by three factors. This result reiterated the results of the conceptual definition phase, which also identified three factors related to the concept in question.

In the factor analysis no item presented a load factor lower than 0.30 , thus, no item was excluded after extraction.
Verification of communality resulted in values ranging from 0.545 and 0.831 . The analysis of internal consistency for each of the factors revealed Cronbach's alpha coefficient of 0.976 for factor 1 "Self-efficacy to connect with families", 0.964 for factor 2 "Self-efficacy to maintain an effective communication with the family" and 0.866 for factor 3 "Self-efficacy to live in harmony with oneself and the family."

Chart 1 presents the allocation of the 39 items on the Self-efficacy Scale for the Establishment of Good Relationships with Families in Neonatal and Pediatric Hospital Settings to the corresponding factors.

Chart 1 - Allocation of the 39 items to the corresponding factors - São Paulo, SP, Brazil, 2015.

\begin{tabular}{|l|c|c|}
\hline \multicolumn{1}{|c|}{ Factor $^{*}$} & Number of items & Matching items \\
\hline 1. Self-efficacy to connect with families & 22 & $\begin{array}{r}16,17,18,19,20,21,22,23,24,25,26,27,28,29, \\
30,31,32,34,35,36,37,39\end{array}$ \\
\hline 2. Self-efficacy to maintain an effective communication with the family. & 13 & $1,2,3,4,5,6,7,8,9,10,11,12,14$ \\
\hline 3. Self-efficacy to live in harmony with oneself and the family. & 4 & $13,15,33,38$ \\
\hline
\end{tabular}

"Original version in portuguese: 1. Autoeficácia para abrir-se para a família. 2. Autoeficácia para manter uma comunicação eficaz com a família. 3. Autoeficácia para conviver em equilíbrio consigo e com a família.

\section{FINAL INSTRUMENT AND SCORE TECHNIQUE}

The Self-efficacy Scale for the Establishment of Good Relationships with Families in Neonatal and Pediatric Hospital Settings is a self-report questionnaire that includes 39 items using a Likert ten-point scale. The score of the total scale and corresponding factors is calculated by totaling the values assigned by the subject for the response gradation of each of the items. The higher the score, the greater the selfefficacy the respondent possesses.

Chart 2 - Score of the total scale and corresponding factors - São Paulo, SP, Brazil, 2015.

\begin{tabular}{|l|c|c|c|}
\hline & Low self-efficacy & Moderate self-efficacy & High self-efficacy \\
\hline Total scale $^{\mathrm{a}}$ & $0-195$ & $196-266$ & $267-390$ \\
\hline${\text { Factor } 1^{\mathrm{b}}}^{\mathrm{c}}$ & $0-114$ & $115-156$ & $157-220$ \\
\hline${\text { Factor } 2^{\mathrm{c}}}^{\mathrm{d}}$ & $0-59$ & $60-87$ & $88-130$ \\
\hline${\text { Factor } 3^{\mathrm{d}}}^{\mathrm{N}}$ & $0-17$ & $18-26$ & $27-40$ \\
\hline
\end{tabular}

a Self-efficacy Scale for the Establishment of Good Relationships with Families in Neonatal and Pediatric Hospital Settings.

bAutoeficácia para abrir-se para a família (Original version in portuguese).

cAutoeficácia para manter uma comunicação eficaz com a família (Original version in portuguese).

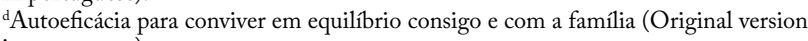
in portuguese).

\section{DISCUSSION}

Theoretically based on Bandura's self-efficacy theory, the Self-efficacy Scale for the Establishment of Good Relationships with Families in Neonatal and Pediatric Hospital Settings is an self-report instrument that takes approximately 15 minutes to be responded and evaluate the self-efficacy of nurses for establishing good relationships with families in neonatal and pediatric settings.

There are four primary sources of information whose people use to determine and modify their personal expectations of self-efficacy: (a) performance accomplishments (personal mastery experiences), (b) vicarious experience (observing others succeed through their efforts), (c) verbal persuasion (encouragement of influential others), and (d) physiological arousal (somatic reactions in relation to potentially stressful and taxing situations) $)^{(6)}$. Using the role playing strategy in small groups during educational interventions is potentially valuable as a source of these four self-efficacy categories of information ${ }^{(20)}$.

The Cronbach's alpha for the entire scale was high at 0.983 while the minimum acceptable value for alpha is $0.70^{(21)}$. The high value of Cronbach's alpha in the Selfefficacy Scale for the Establishment of Good Relationships with Families in Neonatal and Pediatric Hospital Settings indicates that it has high internal consistency and that all items are measuring the same concept.

For item-total correlation, a value greater than 0.3 is recommended ${ }^{(22)}$. The item-total correlation ranged between 0.657 and 0.847 , indicating that all items of the scale contributed to the measurement of the concept of self-efficacy in question, and a lower Cronbach's alpha or equal to 0.983, compared to the exclusion of each item, indicated that all items should be kept in the instrument.

In factor analysis, each of the variables can be defined as a linear combination of common factors that explain part of the variance of each variable (communality). The communality may range from 0 to 1 ; the greater the communality, the greater the explanatory power of that variable by the factor. Ideally the value of communalities should be greater than 0.5 for a satisfactory factor analysis ${ }^{(18)}$. Verification of communality resulted in values between 0.545 and 0.831 , indicating that all items were at least $50 \%$ represented in the factors.

Factor analysis indicated that 22 items should be allocated in factor 1,13 items in factor 2 and 4 items in factor 3. The Cronbach's alpha for each factor was high; 0.976 for factor 1, 0.964 for factor 2 and 0.866 for factor 3. Factor 1 "Self-efficacy to connect with families" consists of items representative of situations seen as challenging for nurses when approaching the family. Factor 2 "Self-efficacy to maintain 
an effective communication with the family" includes items indicative of situations that make it difficult to maintain an effective nurse communication with family and Factor 3 "Self-efficacy to live in harmony with oneself and the family" consists of items representing situations that may hinder the establishment of a harmonious relationship between the self and the family. The elements or situations (items) reflect facts, perceptions, thoughts and feelings of nurses in relation to the family and the nurses in relation to themselves that, in the perception of nurses, can interfere with their self-efficacy belief, that is, in how much nurses believed themselves to be capable of establishing a good relationship with the family. "People have to judge their efficacy not only to sustain their motivation and task-oriented focus but to manage distressing emotional states and self-debilitating thought patterns, which can impair their execution of activities"(23).

Self - efficacy beliefs "contribute significantly to the level of motivation and performance. Efficacy beliefs predict not only the behavioral functioning between individuals at different levels of perceived self-efficacy but also changes in functioning in individuals at different levels of efficacy over time and even variation within the same individual in the tasks performed and those shunned or attempted but failed"(23).

\section{CONCLUSION}

This study provides a scale with psychometric adequacy that allows simple identification of self-efficacy as well as personal barriers and self-evaluation for the detection of elements that need to be improved in nurses to create and maintain successful relationships with families in neonatal and pediatric settings. The final version of the instrument is a ten-point Likert scale with 39 items and three factors, whose the Cronbach's alpha for all items was 0.983 with item-total correlations in the range 0.657 to 0.847 and Cronbach's alpha value if item deleted were less than or equal to 0.983 .

The evaluation made by analysis of participant responses to the Self-efficacy Scale for the Establishment of Good Relationships with Families in Neonatal and Pediatric Hospital Settings may guide development of more effective strategies to prepare and support nursing courses or training strategies to improve nurses'behaviors for establishing successful relationships with families in neonatal and pediatric settings, improving the care that patients and their families receive.

It is proposed to use the scale before and after educational interventions on topics related to patient and family centered care, family systems nursing, communication and interpersonal relationships in the clinical field, research and education, once the assessment of self-efficacy to establish good relationships with families is recognized as an important predictor of behavior change.

Regarding the study limitations, the original version of the instrument was constructed and validated in Brazil and it is available in Portuguese, so, for it can be applied with nurses from different places around the world, it is necessary a scale translation and validation in other languages, stability assessment through test and the establishment and standardization of cut-off points in other populations. Furthermore, for future research it is necessary to verify the criterion-related validity of the Portuguese version of Self-efficacy Scale for the Establishment of Good Relationships with Families in Neonatal and Pediatric Hospital Settings, examining concurrent relationship of the new instrument with similar scales.

\section{RESUMEN}

Objetivo: El propósito de este estudio fue desarrollar y probar las propiedades psicométricas de la Escala de Autoeficacia para el Establecimiento de Buenas Relaciones con las Familias en Ambientes Neonatales y Pediátricos. Método: Estudio metodológico fundamentado en la teoría de la auto-eficacia se realizó en tres fases: conceptual y definición operacional (revisión de la literatura y entrevistas con la población objetivo), la validez de contenido (opinión de cinco expertos y tres enfermeras clínicas), y el factor de análisis exploratorio e fiabilidad interna de consistencia (estudio transversal con una muestra válida de 194 enfermeras). Resultados: La escala de Likert de diez puntos con 40 ítems fue diseñada y un elemento fue excluido después de la revisión por expertos. Hay tres factores que emergieron del análisis factorial exploratorio. El alfa de Cronbach para todas las partidas fue 0,983 , con correlaciones ítem-total en el rango de 0,657 a 0.847. E1 Valor alfa de Cronbach excluyendo el ítem quedo inferior o igual a 0.983. Conclusión: La versión final de la escala demostró psicometría adecuada. Se trata de una herramienta útil para ser administrada en los campos clínicos, educativos y de enfermería de investigación para medir las creencias de autoeficacia de enfermeros sobre el establecimiento de buenas relaciones con las familias.

\section{DESCRIPTORES}

Autoeficacia; Relaciones Profesional-Familia; Enfermería de la Familia; Enfermería Neonatal; Enfermería Pediátrica; Estudios de Validación.

\section{RESUMO}

Objetivo: O propósito deste estudo foi desenvolver e testar as propriedades psicométricas da Escala de Autoeficácia para o estabelecimento de bons relacionamentos com famílias no contexto neonatal e pediátrico hospitalar. Método: Estudo metodológico fundamentado na teoria da autoeficácia foi realizado em três fases: definição conceitual e operacional (revisão de literatura e entrevistas com a população alvo), validade de conteúdo (opinião de cinco especialistas e três enfermeiras clínicas), e análise fatorial exploratória e avaliação de consistência interna (pesquisa transversal com uma amostra válida de 194 enfermeiros). Resultados: Uma escala do tipo Likert de 10 pontos com 40 itens foi desenvolvida e um item foi excluído após a avaliação dos juízes. Três fatores emergiram da análise fatorial. O alfa de Cronbach para todos os itens foi igual a 0,983 com a correlação item-total variando entre 0,657 e 0,847 . O alfa de Cronbach caso determinado item fosse excluído foi menor ou igual a 0,983. Conclusão: A versão final da escala demonstrou adequação psicométrica. Trata-se de uma ferramenta útil que pode ser facilmente aplicada no campo clínico, educacional e de pesquisa para medir o impacto de intervenções nas crenças de autoeficácia dos enfermeiros relacionadas ao estabelecimento de bons relacionamentos com famílias. 


\section{REFERENCES}

1. Princeton DM. The caring phenomenon: a search for absolute good caring. Int J Humanit Sol Sci. 2015;5(1):211-9.

2. Lima AS, Silva VKBA, Collet N, Reichert APS, Oliveira BRG. Relações estabelecidas pelas enfermeiras com a família durante a hospitalização infantil. Texto Contexto Enferm. 2010;19(4):700-8.

3. Coyne I, O'Neill C, Murphy M, Costello T, O'Shea R. What does family-centred care mean to nurses and how do they think it could be enhanced in practice. J Adv Nurs. 2011;67(12):2561-73.

4. Angelo M, Cruz AC. Autoeficácia do enfermeiro para o relacionamento com a família. Rev Referência. 2015;3(IV):151-5.

5. Bandura A. Self-efficacy. In: Ramachandran VS, editor. Encyclopedia of human behavior. New York: Academic Press; 1994. p. 71-81.

6. Bandura A. Self - efficacy: toward a unifying theory of behavioral change. Psychol Rev. 1977;84(2):191-215.

7. Côa TF, Pettengill MAM. The vulnerability experienced by the family of children hospitalized in a pediatric intensive care unit. Rev Esc Enferm USP. 2011;45(4):824-30. DOI: http://dx.doi.org/10.1590/S0080-62342011000400005

8. Cruz AC, Angelo M. Stomas in neonatology: recovering the mother's memory. Rev Esc Enferm USP. 2012;46(6):1306-13. DOI: http://dx.doi. org/10.1590/S0080-62342012000600004

9. Pimenta EAG, Collet N. Dimension of nursing and family care to hospitalized children: conceptions of nursing. Rev Esc Enferm USP. 2009;43(3):619-26.

10. Quirino DD, Collet N, Neves AFGB. Hospitalização infantil: concepções da enfermagem acerca da mãe acompanhante. Rev Gaúcha Enferm. 2010;31(2):300-6.

11. Simpson P, Tarrant M. Development of the Family Nursing Practice Scale. J Fam Nurs. 2006;12(4):413-25.

12. Pasquali L. Instrumentos psicológicos: manual prático de elaboração. Brasília: LabPAM/IPAPP; 1999.

13. Pasquali L. Psychometrics. Rev Esc Enferm USP. 2009;43(n.spe):992-9.

14. Bandura A. Guide for Constructing Self-Efficacy Scales. In: Pajares F, Urdan T, editors. Self-efficacy beliefs of adolescents. Greenwich: Information Age; 2006. p. 307-37.

15. Elo S, Kääriäinen M, Kanste O, Tarja Pölkki T, Utriainen K, Kyngäs H. Qualitative content analysis: a focus on trustworthiness. SAGE Open. 2014:1-10

16. Shi C, Tian J, Wang Q, Petkovic J, Ren D, Yang K, et al. How equity is addressed in clinical practice guidelines: a content analysis. BMJ open. 2014;4:e005660.

17. Pasquali L. Psychometrics: theory test in psychology and education. Petropolis: Vozes; 2003.

18. Hair JF, Black WC, Babin BJ, Anderson RE, L TR. Multivariate data analysis. $7^{\mathrm{a}}$ ed. Upper Saddle River: Prentice Hall; 2009.

19. Horn JL. A Rationale and test for the number of factors in factor analysis. Psychometrika. 1965;30:179-85.

20. Parle M, Maguire P, Heaven C. The development of a training model to improve health professionals'skills, self-efficacy and outcome expectancies when communicating with cancer patients. Soc Sci Med. 1997;44(2):231-40.

21. Streiner DL. Being inconsistent about consistency: when coefficient alpha does and doesn't matter. J Pers Assess. 2003;80(3):217-22.

22. Kline P. The handbook of psychological testing. 2th ed. London: Routledge; 2000.

23. Bandura A, Locke EA. Negative self-efficacy and goal effects revisited. J Appl Psychol. 2003;88(1):87-99. 